\title{
THE ECONOMICS OF SWEET BRIER CONTROL
}

\author{
F. A. MEEKLAH and R. B. MITCHELL \\ Field Research Section, Invermay Agricultural \\ Research Centre, M.A.F., Mosgiel
}

Summary

The costs, time taken, and relative efficiency of 3 methods of control of sweet brier (Rosa rubiginosa) control are reported. Granular picloram was the most expensive, basal herbicide + diesel was considerably cheaper, but foliar applied picloram/ $2,4,5-\mathrm{T}$ was the cheapest. The most efficient treatment in controlling sweet brier was picloram granules, but basal $2,4,5-\mathrm{T}$ or picloram $/ 2,4,5-\mathrm{T}$ in diesel was acceptable. On a cost/efficiency basis, basal herbicide in diesel was the best treatment. Labour input showed no marked advantage for any treatment.

\section{INTRODUCTION}

SWEET brier (Rosa rubiginosa) is widespread throughout New Zealand, although in the North Island it is sporadic and not densely distributed as in the tussock grasslands of the South Island.

The ecology and biology of sweet brier in tussock grassland have been studied by Molloy (1964, Pers. Comm.) who concluded that "compared with the large amount of seed produced there is a general absence of a spate of vigorous seedlings. The field and experimental evidence proves that germination and seedling establishment are the critical phases in the life history of brier. From the practical viewpoint the most significant fact which emerges is that sweet brier seedlings are clearly vulnerable to conventional rasture improvement, whether it be by judicious management of resident vegetation, or by the more profitable method of oversowing and topdressing."

Generally, informed opinion now considers a state of equilibrium to exist between sweet brier and other vegetation on most sites. The problem thus resolves to one of eradicating established bushes since chemical control is fossible, Dingwall (1962), Meeklah (1969) and Upritchard (1969). It is now the prerogative of the run-holder to determine on the basis of a cost/benefit analysis what action to take, for which he needs an indication of the probab!e cost. This paper reports work done in Central Otago which indicates likely treatment costs.

\section{MATERIALS AND METHOD}

Commencing 1968, 3 separate sites in 3 consecutive years were divided into 0.004 hectare plots, discrete brier bushes counted, and the following materials applied at the appropriate time.

1. 2,4,5-T oil miscible concentrate ( $72 \%$ a.i.) in diesel oil. Basal spray, winter. 
2. Picloram 5\%/2,4,5-T $20 \%$ a.i.* in diesel oil. Basal spray, winter.

3. Picloram granules $(2 \%$ a.i. $)$ at $1 \mathrm{gm}$ a.i./15 cm basal stool diameter. Basal application, spring.

4. Picloram $7.5 \% / 2,4,5-\mathrm{T} 20 \%$ a.i. 1 part in 200 parts water. Foliage application, summer (late flowering stage).

Treatments were replicated 3 times in a randomised block design. 'Quantities of materials used and the time taken to apply them were recorded on each occasion.

All were agitated during mixing and application to minimise crystallisation.

Assessments of \% dead wood per bush were taken up to 2 years after application to assess the regrowth potential. To assess total costs/hectare, the following item costs were used:

wages at $\$ 1.36 /$ hour, diesel at $4.1 \mathrm{c} / \mathrm{litre}$, and chemicals at current prices i.e. ester of $2,4,5-\mathrm{T}(72 \%$ a.i.) at $\$ 3.50$ litre, picloram/ $2,4,5-\mathrm{T}(25 \%)$ at $\$ 2.90 /$ litre, picloram $2 \%$ granules at $\$ 1.20 / \mathrm{kg}$.

\section{RESULTS}

Table I shows the number of bushes at each trial site, the quantities of materials used and the time taken to apply them, all estimated as means per hectare, plus the mean \% dead wood per bush at 18/11/71.

The maximum amount of dead wood was frequently recorded in granular picloram treatments: the surviving sweet brier in these plots could usually be ascribed to insufficient herbicide applied, or from a small sucker that had been missed during application.

On the other hand it was noted on bushes treated basally with herbicide in diesel, that surviving canes frequently appeared to be fresh suckers emerging in the growing season immediately following treatment-

The amount of dead wood per bush was low where basal applications of $2,4,5-\mathrm{T}$ and picloram $/ 2,4,5-\mathrm{T}$ were diluted at 1 part in 80 parts of diesel but reached a more satisfactory level when the dilution was reduced to 1 fart in 40 .

Live wood on bushes treated in full foliage with picloram/2,4,5-T generally appeared to be due to surviving canes rather than from increased suckering.

Granular application generally took slightly longer to apply than basal spraying with diesel + herbicide; ocassionally fo:iar application took longer than other methods.

Fig. 1 illustrates the cstimated total cost per hectare. Invariably picloram granules cost more than any other treatment, basal picloram/2,4,5-T in diesel was usually slightly more expensive than $2,4,5-\mathrm{T}+$ diesel, while picloram $/ 2,4,5-T$ was often the cheapest; (in this figure the concentration of basal diesel treatments was taken as 1 part $25 \%$ picloram $/ 2,4,5-\mathrm{T}$ or $.72 \% 2,4,5-\mathrm{T}$ to 40 parts diesel).

*Formulations raried each year as follows:

First year $=$ picloram acid 5\%/octyl ester 2,4,5-T $20 \%$

Second year $=$ octyl ester picloram $5 \%$ /octyl ester 2,4,5-T $20 \%$

Third year $=$ potassium salt picloram $5 \%$ /iso octyl ester $2,4,5-\mathrm{T} 20 \%$ 
Scrub Weeds

TABLE 1: No. OF BUSHES, MATERIALS APPLIED, QUANTITIES: AND TIME TAKEN PER HECTARE, \% DEAD WOOD AS AT $18 / 11 / 71$

\begin{tabular}{|c|c|c|c|c|}
\hline $\begin{array}{l}\text { No. of bushes } \\
\text { per hectare }\end{array}$ & $\begin{array}{l}\text { Basaī } \\
2,4,5-T \\
+ \text { diesel }\end{array}$ & $\begin{array}{l}\text { Basal } \\
\text { picloram } \\
+2,4,5-T \\
+ \text { diesel }\end{array}$ & $\begin{array}{l}\text { Picloram } \\
\text { granules }\end{array}$ & $\begin{array}{l}\text { Foliar } \\
\text { picloram } \\
+2,4,5-T \\
+ \text { water }\end{array}$ \\
\hline 14800 & $\begin{array}{l}710 \text { litres* } \\
27 \text { hrs } \\
98 \%\end{array}$ & $\begin{array}{l}560 \text { litres* } \\
25 \text { hrs } \\
100 \%\end{array}$ & $\begin{array}{l}270 \mathrm{~kg} \\
25 \mathrm{hrs} \\
100 \%\end{array}$ & $\begin{array}{l}710 \text { litres } \\
20 \mathrm{hrs} \\
34 \%\end{array}$ \\
\hline 1300 & $\begin{array}{l}90 \text { litres* } \\
7 \text { hrs } \\
88 \%\end{array}$ & $\begin{array}{l}90 \text { litres* } \\
5 \text { hrs } \\
97 \%\end{array}$ & $\begin{array}{l}60 \mathrm{~kg} \\
10 \mathrm{hrs} \\
87 \%\end{array}$ & $\begin{array}{c}180 \text { litres } \\
5 \text { hrs } \\
66 \%\end{array}$ \\
\hline 20000 & $\begin{array}{c}480 \text { litres* } \\
9 \text { hrs } \\
94 \%\end{array}$ & $\begin{array}{l}570 \text { litres: } \\
10 \text { hrs } \\
99 \%\end{array}$ & $\begin{array}{l}200 \mathrm{~kg} \\
12 \mathrm{hrs} \\
100 \%\end{array}$ & $\begin{array}{c}700 \text { litres } \\
7 \text { hrs } \\
46 \%\end{array}$ \\
\hline 4600 & $\begin{array}{l}340 \text { litres** } \\
30 \text { hrs } \\
16 \%\end{array}$ & $\begin{array}{l}360 \text { litres** } \\
30 \text { hrs } \\
18 \%\end{array}$ & $\begin{array}{l}210 \mathrm{~kg} \\
17 \mathrm{hrs} \\
90 \%\end{array}$ & $\begin{array}{l}850 \text { litres } \\
30 \text { hrs } \\
47 \%\end{array}$ \\
\hline 6200 & $\begin{array}{l}180 \text { litres** } \\
10 \text { hrs } \\
45 \%\end{array}$ & $\begin{array}{l}300 \text { litres** } \\
17 \text { hrs } \\
45 \%\end{array}$ & $\begin{array}{l}240 \mathrm{~kg} \\
20 \mathrm{hrs} \\
100 \%\end{array}$ & $\begin{array}{l}770 \text { litres } \\
25 \mathrm{hrs} \\
69 \%\end{array}$ \\
\hline 7300 & $\begin{array}{l}320 \text { litres** } \\
20 \text { hrs } \\
26 \%\end{array}$ & $\begin{array}{l}300 \text { litres** } \\
17 \text { hrs } \\
23 \%\end{array}$ & $\begin{array}{l}280 \mathrm{~kg} \\
27 \mathrm{hrs} \\
100 \%\end{array}$ & $\begin{array}{l}620 \text { litres: } \\
20 \mathrm{hrs} \\
62 \%\end{array}$ \\
\hline 10700 & $\begin{array}{l}450 \text { litres } * * * \\
25 \text { hrs } \\
84 \%\end{array}$ & $\begin{array}{l}450 \text { litres**** } \\
25 \text { hrs } \\
93 \%\end{array}$ & $\begin{array}{l}270 \mathrm{~kg} \\
25 \mathrm{hrs} \\
100 \%\end{array}$ & $\begin{array}{c}1080 \text { litres } \\
35 \text { hrs } \\
82 \%\end{array}$ \\
\hline 7500 & $\begin{array}{l}540 \text { litres } * * * \\
20 \text { hrs } \\
68 \%\end{array}$ & $\begin{array}{l}380 \text { litres } * * * \\
17 \text { hrs } \\
92 \%\end{array}$ & $\begin{array}{l}340 \mathrm{~kg} \\
30 \mathrm{hrs} \\
95 \%\end{array}$ & $\begin{array}{l}1160 \text { litres } \\
35 \mathrm{hrs} \\
67 \%\end{array}$ \\
\hline 4100 & $\begin{array}{l}280 \text { litres } \% * \% \\
15 \text { hrs } \\
77 \%\end{array}$ & $\begin{array}{l}250 \text { litres } * * * \\
12 \text { hrs } \\
79 \%\end{array}$ & $\begin{array}{c}230 \mathrm{~kg} \\
15 \mathrm{hrs} \\
94 \%\end{array}$ & $\begin{array}{c}740 \text { litres } \\
30 \text { hrs } \\
85 \%\end{array}$ \\
\hline
\end{tabular}

N.B. Concentrations of the basal applications varied each year:

* 1 part herbicide in 20 diesel

** 1 part herbicide in 80 diesel

$* * * 1$ part herbicide in 40 diesel 
IFIg 1 ESTIMATED COST PER HECTARE

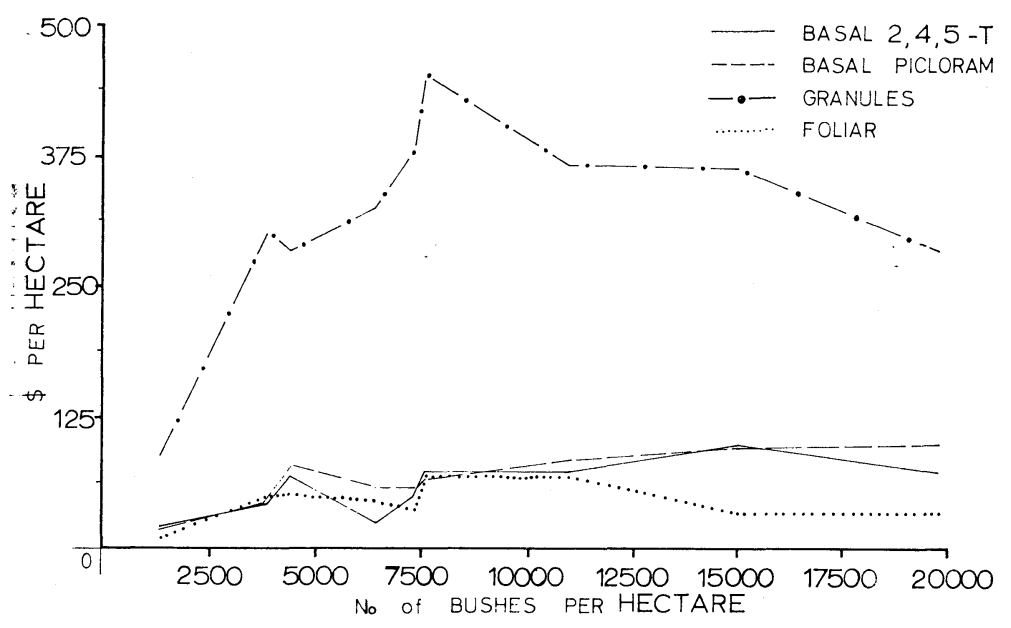

\section{DISCUSSION}

Due regard must be paid to the fact that the inputs/hectare estimated in this paper can only be strictly related to the sites on which the studies were carried out, as no sweet brier stand is reproducible and these estimates must be extrapolated with some reserve.

Large numbers of bushes/hectare were often recorded, particularly at 2 sites, where many plants possessing only 1 or 2 small canes could not reliably be allied as suckers to neighbouring bushes. Sweet brier frequency was extremely variable leading to similar variability in both the amount of materials applied and time taken for application.

It is clear that the most biologically efficient treatment in this study was picloram granules but it was the most costly. However it had the physical advantage that the total weight of materials to be transported per hectare usually was less than that of the liquid mixtures particularly if the weight of spray machinery is added.

Basal application of herbicide + diesel was not quite as efficient in controlling sweet brier but would be considered acceptable by the authors. It was noticeable that regrowth frequently was from suckers: it is hoped that any run-holder who is to control sweet brier with chemicals would previously have undertaken a programime of pasture improvement. Emerging sweet brier suckers would then have to contend with severe pasture competition, plus grazing or trampling from more intensive stocking at *critical growth stages.

Frequently there was better sweet brier control with picloram/2,4,5-T than with 2,4,5-T alone in diesel. Although slightly more expensive and with an added risk of crystallisation if not agitated once mixed with diesel, it is probably worth using this mixture since manual agitation of the knapsack is easy once it is on the operator's shoulders. Poorest control of sweet brier was shown by foliar application of picloram/2,4,5-T; it is 


\section{Scrub Weeds}

probable that the poor control shown in this study was because insufficient chemical was applied to the foliage and stems. Analysis of costs indicates that as chemicals formed the lowest proportion of the total a considerable increase in strength, say to 1 part of $27.5 \%$ picloram/2,4,5-T to 100 * parts water, is possible before the cost of treatment exceeds that of basal herbicide + diesel.

Note that labour costs here do not include the time spent mixing and filling materials used, this may be a factor both logistically and economically that needs added consideration in any cost/benefit analysis.

The above study gives an indication of the probable costs involved in controlling sweet brier, what is now required is an assessment of the' losses caused by sweet brier i.e. in loss of pasture production, and by interference with grazing. Once the run-holder has this information only then can he carry out a cost/benefit analysis. Current indications are that stock losses are negligible while grazing is available over more of the area infested.

\section{CONCLUSIONS}

In this study of sweet brier control it was found that

(a) The most efficient treatment was picloram granules, but control by basal $2,4,5-\mathrm{T}$ or picloram/2,4,5-T in diesel was acceptable.

(b) The most expensive in terms of chemical and application costs was: granular picloram. Basal treatments of $2,4,5-\mathrm{T}$ and of picloram/ $2,4,5-\mathrm{T}$ in diesel were considerably cheaper than granular picloram. Foliar applied picloram $/ 2,4,5-\mathrm{T}$ was the cheapest.

(c) On a cost/efficiency basis, basal herbicide in diesel was the best: treatment.

(d) On a logistical basis granular picloram weighed the least, but if clean water was available on site then foliar applied picloram would bemore efficient.

(e) Labour input showed no marked advantage for any treatment.

\section{A.CKNOWLEDGEMENTS}

To H. McRobb fór assistance throughout this study, Messrs Sidey, Colling and Scurr for provision of sites, and Ivon "Watkins-Dow for supply of experimental materials.

\section{REFERENCES}

Dingwall, A. R., 1962. Sweet brier. Proc. 15th N.Z. Weed \& Pest. Control Conf.: 29-35.

Meeklah, R. A., 1969. 'The control of 'sweet brier with granular herbicides. Proc. 22nd N.Z. Weed \& P'est Cont. Conf.: 187-192.

Molloy, B. P. J., 1964. Sweet brier-a vigorous woody weed in South Island tussock grass!and. N.Z. $J l$ of Ag., 109, No. 2: 105-118.

Molloy, B. P. J., 1964. Synopsis of structure, life history and seasonal behaviour of sweet brier. Proc. 17th N.Z. Weed \& Pest Cont. Conf.: ": "19-27.

'Upritchard, E. A., 1969. Formulations of picloram with 2,4,5-T for brushweed control. Proc 22nd Weed E Pest Cont. Conf.: 180-86. 